\title{
Induction of apoptosis in an estrogen-responsive mouse Leydig tumor cell by leukotriene
}

\author{
H.G. GOTO ${ }^{1,2}$, Y. NISHIZAWA ${ }^{1,2}$, H. KATAYAMA ${ }^{1,2}$, T. MURASHIMA ${ }^{1,3}$, \\ M. YAMASAKI ${ }^{1,2}$, Y. TANIGAKI ${ }^{1}$, S. KIMURA ${ }^{3}$, S. FUSHIKI ${ }^{4}$ and Y. NISHIZAWA ${ }^{4,5}$
}

${ }^{1}$ Department of Pathology, Research Institute, Osaka Medical Center for Cancer and Cardiovascular Diseases, 1-3-3 Nakamichi, Higashinari, Osaka 537-8511; ${ }^{2}$ Laboratory of Clinical and Experimental Pathophysiology, Graduate School of Pharmaceutical Science, Osaka University, Suita, Osaka 565-0871; ${ }^{3}$ Department of Radiochemical Laboratory, Osaka University of Pharmaceutical Sciences, Takatsuki, Osaka 569-1094; ${ }^{4}$ Department of Dynamic Pathology, Research Institute for Neurological Diseases and Geriatrics, Kyoto Prefectural University of Medicine, Kamigyoku, Kyoto 602-8566; ${ }^{5}$ Department of Anesthesiology, Shiga University of Medical Science, Ohtsu, Shiga 520-2192, Japan

Received September 7, 2006; Accepted October 10, 2006

\begin{abstract}
For estrogen-responsive B-1F cells, established from estrogen-responsive mouse Leydig cell tumor, it has been reported that the 5-lipoxygenase (5-LOX) metabolic pathway appears to be associated with cell growth. The addition of 5-LOX inhibitor 2-(12-hydroxydodeca-5,10-diyl)3,5,6-trimethyl-1,4-benzoquinone (AA861) to the medium resulted in a dose-dependent increase in cell yield as described previously. When the growth of the palpable tumors was measured, AA861 had stimulated in vivo tumor growth in adult male mouse inoculated B-1F cells. The effects of AA861 and $17 ß$-estradiol (E2) on the contents of various arachidonic acid metabolites in B-1F cells and their conditioned medium were examined. Although AA861 and E2 decreased the contents of leukotrienes (LTs), the two did not significantly change those of prostaglandins, thromboxan, prostacyclin, 12-hydroxyeicosatetraenoic acid (HETE) and 15-HETE. In immunohistochemical study B-1F cells show positive staining for 5-LOX in the E2-depleted condition, while E2 decreased the expression of 5-LOX. The decrease of the intensities of 79-kDa 5-LOX protein and 403-bp RT-PCR product bands was observed. The growth of Morpholino-anti oligo delivered $\mathrm{B}-1 \mathrm{~F}$ cells was higher than that of Standard control oligo delivered cells. The delivery of Morpholino-anti oligo into $\mathrm{B}-1 \mathrm{~F}$ cells caused the decrease of contents of LTs and 5-HETE in the cells and medium, and the reduction of 5-LOX activity. When LTD4 was added in the culture medium, the increasing concentrations of LTD4 resulted in a significant inhibition of
\end{abstract}

Correspondence to: Dr Yasuko Nishizawa, The Department of Pathology, Research Institute, Osaka Medical Center for Cancer and Cardiovascular Diseases, 1-3-3 Nakamichi, Higashinari, Osaka 537-8511, Japan

E-mail: nisizawa-ya@mc.pref.osaka.jp

Key words: 5-lipoxygenase, leukotriene, growth, estrogen cell yields of E2-treated B-1F cells. Morphological changes such as nuclear condensation and fragmentation, and DNA ladder pattern were demonstrated in E2-stimulated B-1F cells treated with LTD4 as well as in control cells cultured in the basal medium. These results implicate that 5-LOX at least plays an important role in the growth of B-1F cells and LD4 induces the apoptosis of B-1F cells.

\section{Introduction}

Tumor cells are derived from cells which constitute the body and retain their original features to various degrees. In a physiological condition, in the target cells of hormones, increase or decrease of cell population is caused by hormonal stimulation. When the stimulation disappears, the cell population returns to basal levels. Endometrial and mammary glands are good examples of this. In these tissues, the growth of the target cells is regulated in response to menstrual cycle and hormonal state in pregnancy. In the growth of tumor cells which originate from these target cells, hormones play important roles and thus they are called hormone-dependent tumors. Mammary and endometrial cancers are representative examples of the female sex hormone-dependent tumors. The representative of the androgen-dependent tumor is prostate cancer. The cell line B-1F was established from estrogenresponsive mouse Leydig cell tumor (T124958-R) in our laboratory in order to study the mechanism of steroid hormonedependent cancer growth (1). 17ß-Estradiol (E2) stimulated the growth of $\mathrm{B}-1 \mathrm{~F}$ cells in a dose-dependent manner, the maximum effect being at a range of $10^{-8} \sim 10^{-7} \mathrm{M}$ (1). When the growth of the palpable tumors was measured to delineate the in vivo proliferative behavior of B-1F cells inoculated s.c. into adult male mice, E2 had significantly stimulated the tumor growth (1).

There are three major metabolic pathways of arachidonic acid, the cyclooxygenase (COX) pathway, lipoxygenase (LOX) pathway and cytochrome p450 pathway $(2,3)$. It is known that NSAIDs (nonsteroidal anti-inflammatory drugs) affect the development of colorectal cancers (4-6) and familial 
adenomatous polyposis $(5,6)$. The major target and mechanism of NSAIDs' effects on the cancers were thought to be cyclooxygenase-2 (COX-2). However, the involvement of other molecular targets besides COX-2 has now been shown (7-12). For estrogen-responsive B-1F cells, we have reported that the 5-lipoxygenase (5-LOX) metabolic pathway appears to be associated with cell growth (13-19). Moreover, there are reports of a relationship between 5-LOX metabolites and the growth of prostate and pancreas cancers $(20,21)$. Hormonedependent cancers are characteristic in the control of their growth by hormones. It was expected that the knowledge obtained from the study of hormone-dependent cancers would be useful for the development of treatment and prevention of not only hormone-dependent cancers but also other cancers. Therefore, additional studies were conducted on the role of 5 -LOX in the estrogen-responsive growth of B-1F cells.

\section{Materials and methods}

Cell culture. B-1F cells were maintained in Eagle's minimum essential medium-Ham's F12 (1:1, vol/vol) containing $0.1 \%$ (wt/vol) bovine serum albumin (BSA) (HMB medium, basal medium) supplemented with $10^{-8} \mathrm{M} \mathrm{E} 2$ (HMBE medium) in a humidified atmosphere of $5 \% \mathrm{CO}_{2}$ at $37^{\circ} \mathrm{C}$. Cells were grown to confluence and passaged with the use of trypsin $(0.01 \%, \mathrm{wt} / \mathrm{vol})$-EDTA $(0.02 \%, \mathrm{wt} / \mathrm{vol})$ in phosphate-buffered saline (PBS).

Cell growth experiment. The effects of appropriate treatments on the cell yield or DNA synthesis were examined with slight modification as previously published $(15,18,19)$. Briefly, cells were plated into four replicate $35-\mathrm{mm}$ dishes at an initial density of $1 \times 10^{4}$ cells/dish in $2 \mathrm{ml}$ of HMB medium. On the following day (day 0), the medium was replaced with $2 \mathrm{ml}$ of HMB medium with or without the appropriate treatments. Test compounds were dissolved as directed in the manual from the supplier. The cells were cultured with new media every other day. When leukotrienes (LTs) were used as test compounds, the culture media were changed every day due to their instability. At the indicated times, the cells were harvested with trypsin-EDTA solution. The viable cells were counted with a hemocytometer using the trypan blue dye exclusion method on day 6 , unless otherwise specified. [Methyl-1',2'$\left.{ }^{3} \mathrm{H}\right]$-thymidine incorporation assay was also performed as described previously $(13,18)$. B-1F cells were plated onto a 96-well plate at an initial density of $4 \times 10^{3}$ cells/well in $0.15 \mathrm{ml}$ of HMB medium, and on the next day (day 0) the medium was replaced with $0.15 \mathrm{ml}$ of HMB medium with or without test compounds. On day 3 , the cells were pulsed with $\left[{ }^{3} \mathrm{H}\right]-$ thymidine $(0.15 \mu \mathrm{Ci} / 0.15 \mathrm{ml}$ per well $)$ for $2 \mathrm{~h}$ at $37^{\circ} \mathrm{C}$ in a humidified incubator. The incorporation of radioactivity into the cells that were briefly trypsinized and collected with a Micro96 Harvester (Molecular devices, USA) was measured.

In vivo growth. The male Balb/c mice (seven-week-old) were obtained from SLC Co. (Shizuoka, Japan), housed 5/cage in a temperature-controlled $\left(25^{\circ} \mathrm{C}\right)$ room with a 12-h light/dark cycle, and given ad libitum access to water and powdered diets. After being harvested and washed, B-1F cells $\left(5 \times 10^{5}\right)$ dispersed in MEM were injected subcutaneously (s.c.) into castrated male Balb/c mice. On the following day (day 0) mice were subcutaneously implanted with a fused pellet of $5 \%$ E2 in cholesterol or started on diets supplemented with or without $0.615 \%$ (w/w) 2-(12-hydroxydodeca-5,10-diyl)3,5,6-trimethyl-1,4-benzoquinone (5-LOX selective inhibitor, AA861) (22). Palpable tumor was measured with a caliper at the indicated times. The tumor volume (v) was then calculated by the formula: $v=4 / 3 \pi \sqrt{ }(a / 2 x b / 2)^{3}$, where $a$ and $b$ are the largest and the smallest diameter of the tumor, respectively.

Immunohistochemistry for 5-LOX. Immunohistochemistry for 5-LOX was performed using a TSA ${ }^{\mathrm{TM}}$ (Tyramide Signal Amplification) Plus DNP system as directed in the manual from the supplier.

$\mathrm{B}-1 \mathrm{~F}$ cells were grown in four-well chamber slides (Falcon) at an initial cell density of $2 \times 10^{4}$ cells/well in HMB medium. On the following day (day 0 ), the medium was changed to HMB medium with or without E2. On day 4, the medium was aspirated, and cells were fixed in $4 \%$ paraformaldehyde in $0.1 \mathrm{M}$ phosphate buffer at $4^{\circ} \mathrm{C}$ for $30 \mathrm{~min}$, and washed in three changes of PBS, followed by freezing-thawing. The chamber slides were incubated for $15 \mathrm{~min}$ in $0.3 \%$ hydrogen peroxide in methanol to quench endogenous peroxidase activity and washed three times in PBS containing $0.01 \%$ (v/v) Tween-20 (PBS-T) for 5 min each. Following rinses, for antigen retrieval before the immunostaining, the slides were immersed in a container with $0.01 \mathrm{M}$ citrate buffer, $\mathrm{pH}$ 6.0, and microwaved for $10 \mathrm{~min}(600 \mathrm{~W}, 5 \mathrm{~min}$, twice). The container with slides was then cooled for approximately $20 \mathrm{~min}$ at room temperature. After rinsing three times in TNT buffer (0.1 M Tris/HCl, pH 7.5, $0.15 \mathrm{M} \mathrm{NaCl}, 0.05 \%$ Tween-20) for $5 \mathrm{~min}$ each, the slides were incubated for $30 \mathrm{~min}$ in TNB buffer $(0.1 \mathrm{M}$ Tris/ $\mathrm{HCl}, \mathrm{pH} 7.5,0.15 \mathrm{M}$ $\mathrm{NaCl}, 0.5 \%$ blocking reagent supplied in kit). Then, the slides were incubated with primary antibody (final 1000-fold dilution) against mouse 5-LOX for $60 \mathrm{~min}$ at room temperature. Primary antibody was incubated for $60 \mathrm{~min}$ at $37^{\circ} \mathrm{C}$ with Envision+l Peroxidase $^{\mathrm{TM}}$ (mouse) in order to form a primary-secondary antibody complex prior to use. After washing three times for 5 min each with TNT buffer the slides were incubated with dinitrophenyl (DNP)-labeled amplification reagent for $5 \mathrm{~min}$ at room temperature followed by washing three times for $5 \mathrm{~min}$ each with TNT buffer. The slides were incubated with antiDNP-HRP (horseradish peroxidase) in TNB buffer for $30 \mathrm{~min}$ at room temperature, washed three times for $5 \mathrm{~min}$ each with TNT buffer and then incubated with diaminobenzidine tetrahydrochloride (DAB) for $5 \mathrm{~min}$ at room temperature until the desired stain intensity developed. The slides were counterstained in hematoxylin for $5 \mathrm{sec}$, washed with tap water, dehydrated through alcohols and xylene, mounted, and observed by light microscopy. For the negative control, the primary antibody was replaced with isotype-matched negative control antibody (Dako), which showed no specific reactivity.

Western blotting. B-1F cells were plated on culture dishes at a density of $5 \times 10^{5}$ cells $/ 100-\mathrm{mm}$ dish in HMB. On the following day (day 0), the medium was changed to HMB or HMBE. On day 4, B-1F cells were scraped into lysis buffer (PBS, $2 \mathrm{mM}$ sodium vanadate $1.0 \mathrm{mM}$ sodium fluoride, $1 \%$ NP40, $0.5 \%$ sodium deoxycholate, $0.1 \%$ SDS, $100 \mu \mathrm{g} / \mathrm{ml}$ 
PMSF, $25 \mu \mathrm{g} / \mathrm{ml}$ aprotinin, $25 \mu \mathrm{g} / \mathrm{ml}$ leupeptin, $25.0 \mu \mathrm{g} / \mathrm{ml}$ pepstatin) at $4^{\circ} \mathrm{C}$. Cell lysates were clarified by microcentrifugation at $12,000 \mathrm{x} \mathrm{g}$ after incubation on ice for $25 \mathrm{~min}$. The supernatants were recovered and their protein concentrations were measured using Bio-Rad protein assay reagent. The supernatants ( 100-500 $\mu$ g protein) were immunoprecipitated with anti 5-LOX mouse monoclonal antibody. For immunoblotting, equivalent amounts of immunoprecipitates were separated by SDS-PAGE and transferred to PVDF membranes by electroblotting using a Bio-Rad semidry transfer blotting apparatus (Nippon Eido Co.) The membranes were subsequently blocked in PBS-T with 5\% nonfat milk overnight at $4^{\circ} \mathrm{C}$ and then incubated with anti 5-LOX mouse monoclonal antibody diluted 1:100 in PBS-T for $1 \mathrm{~h}$ at room temperature. After incubation the membranes were washed in PBS-T and then incubated with horseradish peroxidase-conjugated antimouse secondary antibodies [Envision+/Peroxidase ${ }^{\mathrm{TM}}$ (mouse)] at a dilution of 1:1000 for $1 \mathrm{~h}$ at room temperature. The membranes were washed, detected by chemiluminescence (ECL reagent kit) and exposed to X-ray film for 1-5 min.

$R T-P C R$ analysis. B-1F cells were plated on culture dishes at a density of $2 \times 10^{6}$ cells $/ 100-\mathrm{mm}$ dish in HMB. On the following day (day 0), the medium was changed to HMB or HMBE. On day 4, total RNA was isolated from B-1F cells using the TRIzol reagent (Invitrogen), according to the manufacturer's protocol. RT-PCR was performed as directed in the manual from the supplier (Qiagen OneStep RT-PCR kit) using specific primers: 5-LOX, 5'-ATGGATGGAGTGG AACCCCGG-3' (upstream) and 5'- CTGTACTTCCTGTTC TAAACT-3' (downstream); and GAPDH (32 cycles), 5'-AT CTTCCAGGAGCGAGACCCCA-3' (upstream) and 5'-TCC ACAATGCCAAAGTTGTCATGG-3' (downstream). The RT profile for 5-LOX was $50^{\circ} \mathrm{C}$ for $30 \mathrm{~min}$ and $95^{\circ} \mathrm{C}$ for $15 \mathrm{~min}$. The PCR profile was $94^{\circ} \mathrm{C}$ for $45 \mathrm{sec}, 46^{\circ} \mathrm{C}$ for $45 \mathrm{sec}$, and $72^{\circ} \mathrm{C}$ for $1 \mathrm{~min} 30 \mathrm{sec}$ for 25 cycles. The PCR profile for 5 -LOX was performed twice. The RT profile for GAPDH was $42^{\circ} \mathrm{C}$ for $30 \mathrm{~min}$ and $95^{\circ} \mathrm{C}$ for $10 \mathrm{~min}$. The RT-PCR profile was $94^{\circ} \mathrm{C}$ for $45 \mathrm{sec}, 55^{\circ} \mathrm{C}$ for $45 \mathrm{sec}$, and $72^{\circ} \mathrm{C}$ for $2 \mathrm{~min}$ for 35 cycles.

The final PCR products were separated on a $2 \%$ agarose gel with ethidium bromide and visualized under UV light. Negative control for 5-LOX RT-PCR that contained no reverse transcriptase showed no PCR products (data not shown).

Delivery of Morpholino oligonucleotide into B-1F cells. Morpholino antisense oligonucleotides (M-anti oligos) and standard control oligos (Std. Ctl. oligos) fluoresceinated at the 3 ' end were purchased from Gene Tools, LLC (Philomath, OR, USA). The sequence of M-anti oligos against mouse 5-LOX mRNA, located at the translation initiation site is 5'-CCACGGTGACAGTGTAGGAGGGCAT-3' and the sequence of standard control oligos (Std. Ctl. oligos) is 5'CCTCTTACCTCAGTTACAATTTATA-3'. M oligos were dissolved in water at a concentration of $0.5 \mathrm{mM}$ (stock solution). The delivery of $\mathrm{M}$-anti or standard control oligos into B-1F cells was performed as directed in the manual from the supplier. The special delivery system delivers M-oligos into the cytosol/nuclear compartment of the cells using Ethoxylated polyethylenimine (EPEI) with Morpholino/DNA duplexes. After incubation with the complete delivery solution containing M-anti or standard control oligos for $3 \mathrm{~h}, 1 \times 10^{4}$ or $2 \times 10^{6}$ cells/dish of B-1F were plated in $35-$ or $60-\mathrm{mm}$ dishes, respectively for cell growth or LT assay.

Assay of arachidonic acid metabolites. The contents of various arachidonic acid metabolites in $\mathrm{B}-1 \mathrm{~F}$ cells and their conditioned medium were examined as previously described $(13,15)$. Briefly, B-1F cells were seeded at a cell density of $1 \times 10^{6}$ cells $/ 60-\mathrm{mm}$ dish in $3 \mathrm{ml}$ of HMB. On the following day (day 0 ), the various test compounds were added to the medium. After 2 days, the medium was replaced with fresh medium containing the same compound. After incubation for a further $7 \mathrm{~h}$, the medium and cells were collected separately, and the viable cells were counted with a hemocytometer using the trypan blue dye exclusion method. The cells were washed in fresh medium and homogenized in $10 \mathrm{ml}$ of ice-cold PBS. In this condition the cell yield per dish was not significantly different between cells irrespective of the presence of test compounds. Various metabolites were separated by reversephase HPLC. LTs present in the cells and medium were measured as described previously $(13,15)$. In our system, the extraction efficiency for LTC4 was $60 \pm 4 \%$ (data not shown). The radioimmunoassay for LTs was performed as directed in the manual from the supplier, using LTB4 or LTC4 kits. The peak areas were estimated for other metabolites of arachidonic acid.

Lipoxygenase assay. The activities of lipoxygenases (5-LOX and 12-LOX) were measured by incubation of the cytosol with $\left[{ }^{3} \mathrm{H}\right]$-arachidonic acid. In these assays, B-1F cells were precultured in HMB for 1 day and then in fresh HMB containing the test compounds for 2 days. On the day of the assay further stimulation with the test compounds for $7 \mathrm{~h}$ was performed. Then, B-1F cells were twice homogenized in $7 \mathrm{vol}$ of $20 \mathrm{mM}$ Tris- $\mathrm{HCl}$ (pH 7.8 at $20^{\circ} \mathrm{C}$ ) $-5 \mathrm{mM}$ dithiothreitol with Polytron PT-10 at setting 5 for $10 \mathrm{sec}$ and 10 -sec cooling followed each burst. The homogenate was centrifuged at 105,000 x g for $60 \mathrm{~min}$. For the assay of the 5-LOX activity, the aliquots of the cytosol were incubated with $10 \mu \mathrm{M}\left[{ }^{3} \mathrm{H}\right]$-arachidonic acid $\left(2-3 \times 10^{6} \mathrm{dpm}\right)$ in $50 \mathrm{mM}$ potassium phosphate buffer at $\mathrm{pH} 7.4$, $2 \mathrm{mM} \mathrm{CaCl}_{2}, 1 \mathrm{mM}$ glutathione and $2 \mathrm{mM} \mathrm{ATP}$ at $30^{\circ} \mathrm{C}$ for $5 \mathrm{~min}$ in a final volume of $0.2 \mathrm{ml}$. For the assay of the 12LOX activity, the mixture contained $50 \mathrm{mM}$ Tris- $\mathrm{HCl}$ buffer at $\mathrm{pH} 7.4,25 \mu \mathrm{M}\left[{ }^{3} \mathrm{H}\right]$-arachidonic acid $\left(2-3 \times 10^{6} \mathrm{dpm}\right)$, and the aliquots of the cytosol in a final volume of $0.2 \mathrm{ml}$. Reactions were performed at $30^{\circ} \mathrm{C}$ for $5 \mathrm{~min}$. Hydroxyeicosatetraenoic acids (HETEs) that formed were separated using HPLC and the radioactivity in fractions for 5-HETE and12-HETE was counted to quantify 5-LOX and 12-LOX activity. PLA2 activity was estimated as arachidonic acid release from B-1F cells. Arachidonic acid release from B-1F cells was measured as previously published (15).

Detection of apoptosis. B-1F cells were plated on culture dishes at a density of $5 \times 10^{5}$ cells/100-mm dish in HMB. On the following day (day 0), the medium was changed to HMBE with or without $10^{-7} \mathrm{M}$ LTD4. As a control, the medium was changed to HMB. The medium was changed again on day 3 . On day 4, floating and attached cells in all dishes of the same 

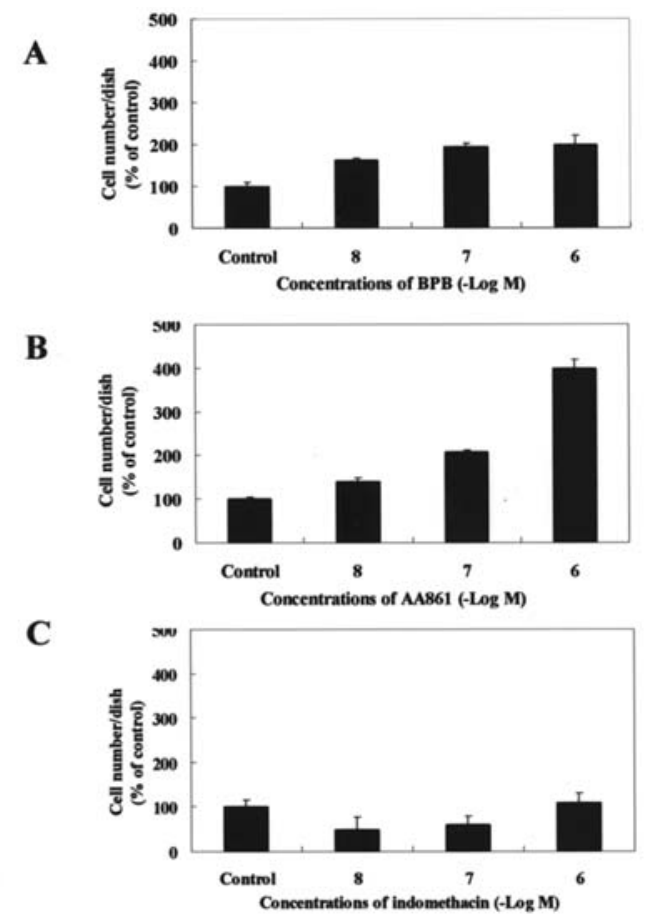

Figure 1. Effects of BPB, AA861 or Indomethacin on the growth of B-1F cells. B-1F cells were treated with or without BPB (A), AA861 (B) or Indomethacin $(C)$ at the indicated concentrations for 6 days. The number of viable cells per dish was counted on day 6 and expressed as a percentage of the cells grown in the absence of test compounds. Concentrations of test compounds are expressed at the negative logarithm values of their molar concentrations. Columns, means of four determinations; bars, SE. The other 2 separate trials also gave similar results.

group were collected together and suspended in PBS. Aliquots of suspension were used to extract fragmented DNA as directed in the manual from the supplier of the ApopLadder EX ${ }^{\mathrm{TM}}$. Fragmented DNA extracted from approximately $1 \times 10^{6}$ cells was eletrophoresed on a $2 \%$ NuSieve (3:1) agarose gel $(12 \times 13 \mathrm{~cm})$ for $2 \mathrm{~h}$ at $65 \mathrm{~V}$. After electrophoresis, the gel was stained with ethidium bromide $(0.5 \mu \mathrm{g} / \mathrm{ml})$ for $10 \mathrm{~min}$ at room temperature, washed with distilled water and photographed. For morphological examination B-1F cells were fixed in $2 \%$ glutalaldehyde in $0.1 \mathrm{M}$ phosphate buffer at $4^{\circ} \mathrm{C}$ for $2 \mathrm{~h}$, stained with Hoechst 33342 (final concentration $0.167 \mathrm{mM}$ ) and examined by fluorescence microscopy.

Materials. Materials were obtained from the following sources: M-oligos from Gene Tools, LLC (Philomath); LTD4 from Cayman Chemical Co. (Ann Arbor, MI); BSA (crystallized and lyophilized), trypsin from Sigma Chemical Co. (St. Louis, MO); Eagle's minimum essential medium, Ham's F12 from Nissui Pharmaceutical Co. (Tokyo, Japan); $\left[{ }^{3} \mathrm{H}\right]$-arachidonic acid, LTB4 and LTC4 $\left[{ }^{3} \mathrm{H}\right]$ RIA kits from DuPont/NEN Research Products (Wilmington, DE); the materials for HPLC from Waters Associates (Bedford, MA); anti-5-LOX monoclonal mouse antibody from Transduction Lab.; Envision $+^{\mathrm{TM}}$ polymer (peroxidase, mouse), normal goat serum, mouse IgG1 from Dako; DAB from Nitirei Co.; TRIzol reagent from Gibco; RNA OneStep RT-PCR kit from Qiagen; NuPage Bis-Tris gel from Invitrogen; ECL Western Blotting Kit, [methyl-1'2'-33]thymidine from Amersham Biosciences Co. (NJ, USA);

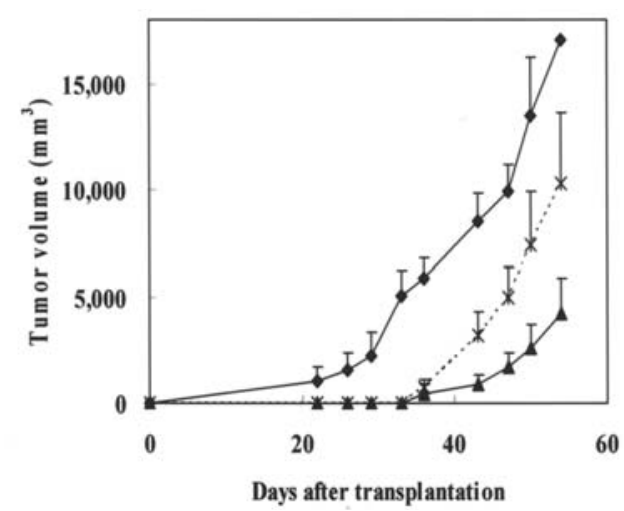

Figure 2. Effect of AA861 on the growth of B-1F cells in vivo. B-1F cells were subcutaneously inoculated into castrated male Balb/c mice. On the following day (day 0) feeding with diets supplemented with or without AA861 was started. Mice were also implanted fused pellet of 5\% E2 in cholesterol. Palpable tumor was measured with a caliper at indicated times. The tumor volume was then calculated by the formula shown in Materials and methods. Columns, means of six determinations; bars, SE. The other 2 separate trials also gave similar results. ^, E2; X, AA861; «, none.

Bio-Rad Protein Assay reagent from Bio-Rad; TSA ${ }^{\mathrm{TM}}$ Plus DNP (HRP) System from NEN Life Science Products. The other reagents used were of analytical grade.

Statistics. The data were expressed as mean \pm standard error (SE). Data were analyzed by ANOVA with Dunnett or Bonferroni's corrections for multiple comparisons, as appropriate. Calculated p values of less than 0.05 were considered to be significant.

\section{Results}

Possible linkage between E2-responsive growth and arachidonic acid metabolism. Arachidonic acid metabolism inhibitors were incubated with B-1F cells in the absence of E2. As previously described $(13,14)$ and shown in Fig. 1, an addition of AA861 to the HMB medium resulted in a dose-dependent increase in cell yield at a range of $10^{-8}$ to $10^{-6} \mathrm{M}$. The phospholipase A2 inhibitor, $p$-bromophenacyl bromide (BPB) was examined for its growth-stimulatory activity. While BPB was less potent than AA861, it showed growth-stimulatory activity. The cyclooxygenase inhibitor, Indomethacin, did not elicit a significant effect on B-1F cell growth at a range of $10^{-8}$ to $10^{-6} \mathrm{M}$. To study the in vivo effect of AA861 on the B-1F cell growth, the cells were inoculated s.c. into intact adult male mice (Fig. 2). As positive control, mice were treated with E2 pellet. The incidence of tumor growth was not different between AA861-treated mice and non-treated mice (6 to 10 for AA861-treated mice, 6 to 10 for non-treated mice). When the growth of the palpable tumors was measured, AA861 stimulated the tumor growth. Although statistical significance was not shown in this experiment (Fig. 2), the other 2 separate trials also gave similar results.

Arachidonic acid metabolites in B-1F cells and their conditioned medium. The effects of AA861 and E2 on the contents of various arachidonic acid metabolites in B-1F cells and their conditioned medium were examined. As shown in 
Table I. Arachidonic acid metabolites.

\begin{tabular}{|c|c|c|c|c|c|c|c|c|c|c|}
\hline \multirow{3}{*}{$\begin{array}{l}\text { Arachidonate } \\
\text { metabolites }\end{array}$} & \multicolumn{5}{|c|}{ Medium } & \multicolumn{5}{|c|}{ Cell } \\
\hline & \multicolumn{3}{|c|}{ E2 } & \multirow{2}{*}{$\begin{array}{l}\text { INDO } \\
10^{-6} \mathrm{M}\end{array}$} & \multirow{2}{*}{$\begin{array}{l}\text { AA861 } \\
10^{-6} \mathrm{M}\end{array}$} & \multicolumn{3}{|c|}{ E2 } & \multirow{2}{*}{$\begin{array}{l}\text { INDO } \\
10^{-6} \mathrm{M}\end{array}$} & \multirow{2}{*}{$\begin{array}{l}\text { AA861 } \\
10^{-6} \mathrm{M}\end{array}$} \\
\hline & $10^{-6} \mathrm{M}$ & $10^{-8} \mathrm{M}$ & $10^{-10} \mathrm{M}$ & & & $10^{-6} \mathrm{M}$ & $10^{-6} \mathrm{M}$ & $10^{-10} \mathrm{M}$ & & \\
\hline 5HETE & 8 & 57 & 98 & 107 & 41 & 10 & 51 & 103 & 111 & 46 \\
\hline 5HPETE & 10 & 39 & 100 & 102 & - & 10 & 48 & 100 & 102 & - \\
\hline 12HETE & 102 & 98 & 104 & 104 & 110 & 100 & 102 & 100 & 106 & 100 \\
\hline 12HPETE & 104 & 106 & 102 & 109 & 111 & 90 & 107 & 100 & 97 & 93 \\
\hline 15HETE & 99 & 97 & 100 & 110 & 104 & 103 & 103 & 103 & 102 & 100 \\
\hline 15HPETE & 107 & 103 & 105 & 101 & 99 & 97 & 85 & 93 & 103 & 101 \\
\hline $\mathrm{LTB}_{4}$ & 8 & 30 & 99 & 105 & 22 & 8 & 26 & 101 & 106 & 19 \\
\hline $\mathrm{LTC}_{4}$ & 7 & 23 & 102 & 122 & 19 & 6 & 23 & 105 & 108 & 9 \\
\hline $\mathrm{LTD}_{4}$ & 9 & 27 & 89 & 112 & 27 & 8 & 30 & 102 & 117 & 23 \\
\hline $\mathrm{LTE}_{4}$ & 7 & 22 & 99 & 113 & 29 & 7 & 31 & 98 & 101 & 30 \\
\hline $\mathrm{PGE}_{2}$ & 95 & 76 & 83 & 3 & 127 & 94 & 104 & 100 & 2 & 100 \\
\hline $\mathrm{PGD}_{2}$ & ND & ND & ND & ND & ND & ND & ND & ND & ND & ND \\
\hline $\mathrm{PGF}_{2 \alpha}$ & 104 & 108 & 106 & 13 & 88 & 106 & 100 & 94 & 8 & 117 \\
\hline $\mathrm{TxB}_{2}$ & ND & ND & ND & ND & ND & ND & ND & ND & ND & ND \\
\hline 6keto-PGF ${ }_{1 \alpha}$ & ND & ND & ND & ND & ND & ND & ND & ND & ND & ND \\
\hline
\end{tabular}

Arachidonic acid metabolites produced by B-1 cells after stimulation in the presence of various concentrations of Estrogen (E2), $10^{-6} \mathrm{M}$ AA861 or $10^{-6} \mathrm{M}$ Indomethacin (INDO) were measured. The results are expressed as \% relative to control, unstimulated cells. ND, no detectable values. The data represent the average of at least two experiments, each performed in five replicates.

Table I and our previous report (13), the contents of LTs decreased to $20 \%$ in the cells and $24 \%$ in the conditioned medium by $10^{-6} \mathrm{M}$ AA861. E2 $\left(10^{-8} \mathrm{M}\right)$ suppressed the contents of LTs to $\sim 27 \%$ in the cells and $26 \%$ in the conditioned medium. Although AA861 and E2 decreased the contents of LTs in B-1F cells, the two did not significantly change those of prostaglandins, thromboxan, prostacyclin, 12-HETE and 15HETE in B-1F cells and their conditioned medium (Table I).

The expression of 5-LOX in B-1F cells. Immunohistochemical study for 5-LOX was carried out in E2-treated and E2-untreated $\mathrm{B}-1 \mathrm{~F}$ cells. Since the activity of $5-\mathrm{LOX}$ in B-1F cells is very low compared with stimulated leukocytes (data not shown), the detection of 5-LOX was difficult by a usual immunohistochemical detection method. Therefore, the TSA method was used in this experiment. B-1F cells show positive stain for 5-LOX under the E2-depleted condition, while E2 decreased the expression of 5-LOX (Fig. 3). Moreover, this E2-responsive decrease of the expression of 5-LOX was confirmed at the levels of protein and mRNA by Western blot analysis and RT-PCR for 5-LOX. Fig. 3 shows the significant decrease of the intensities of 79-kDa 5-LOX protein and 403-bp RT-PCR product bands.

Delivery of Morpholino oligonucleotide into B-1F cells. Gene function and control can be studied with the appropriate antisense oligo. M-anti oligo is a novel antisense structural type that belongs to RNAase-H independent oligonucleotides and exhibits higher antisense activity, higher water solubility,
$\mathbf{A}$

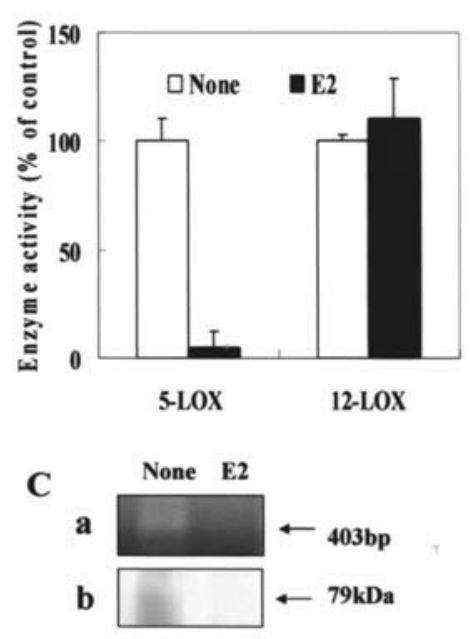

B

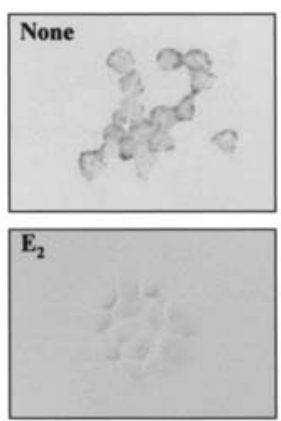

Cont.

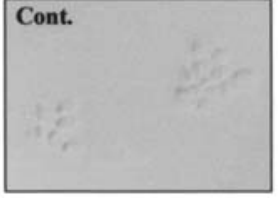

Figure 3. Suppressive effect of E2 on 5-LOX activity. The 5-LOX and 12-LOX activities (A) were estimated in B-1F cells with or without E2 stimulation as described in Materials and methods. Immunohistochemistry of 5-LOX in B-1F cells was carried out (B). The expression of 5-LOX mRNA and protein in B-1F cells was also examined (C). C, (a) RT-PCR; (b) Western blot analysis.

and more resistance to nucleases in target cells than the mostly used phosphorothioate oligonucleotides. These type of antisense oligonucleotides against 5-LOX mRNA were used to examine the role of $5-\mathrm{LOX}$ in $\mathrm{B}-1 \mathrm{~F}$ cell growth. The 
A

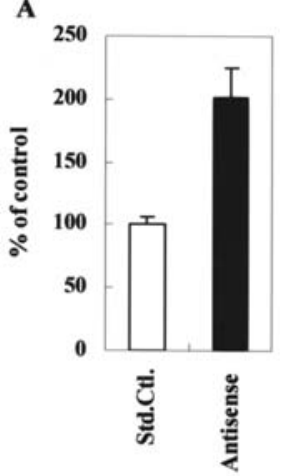

A

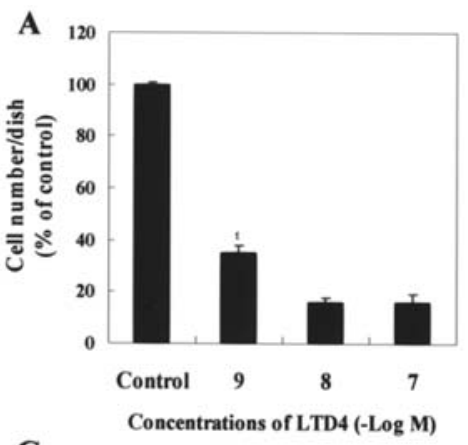

C

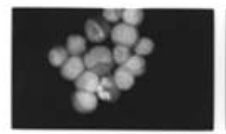

B

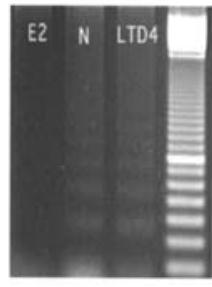

Figure 4. Effect of M-anti oligos against 5-LOX mRNA on the growth of $\mathrm{B}-1 \mathrm{~F}$ cells. B-1F cells were delivered with $\mathrm{M}$-anti oligos against 5-LOX mRNA or Std. Ctl. Oligos. The number of viable cells per dish was counted on day $6(\mathrm{~A})$, and $\left[{ }^{3} \mathrm{H}\right]$-thymidine incorporation was estimated on day $3(\mathrm{~B})$. Columns, means of four experiments; bars, SE. The other 2 separate trials also gave similar results.

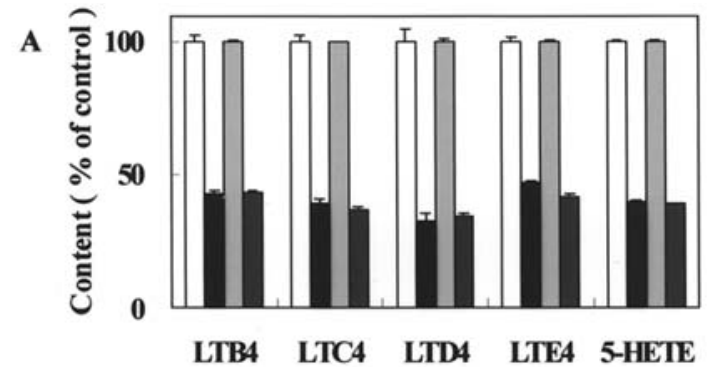

B

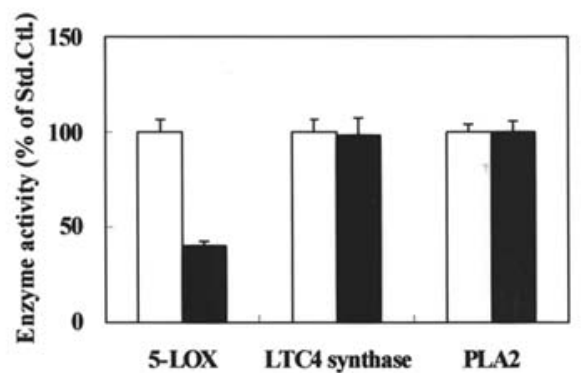

Figure 5. LT contents in B-1F cells and released by B-1F cells delivered with $\mathrm{M}$-anti oligos against 5-LOX mRNA, and effects of M-anti oligos against 5-LOX mRNA on enzyme activities. B-1F cells were delivered with M-anti oligos against 5-LOX mRNA or Std. Ctl. oligos. As described in Materials and methods, LTs were separated by reverse-phase HPLC and estimated. A, LTs produced by B-1F cells and released by B-1 cells into the medium. White, Std. Ctl. oligos (medium); black, M-anti oligos (medium); dotted, Std Ctl. oligos (cell); striped, M-anti oligos (cell). B, 5-LOX, LTC4 synthase and PLA2 activities in B-1F cells were estimated in Materials and methods. White, Std. Ctl. oligos; black, M-anti oligos. Columns, means of five determinations; bars, SE. LT contents and enzyme activities were expressed as a percentage of those in B-1F cells delivered with Std. Ctl. oligos.

delivery of M-anti oligos into B-1F cells was confirmed by the intracellular fluorescence (data not shown). The growth of M-anti oligo delivered B-1F cells was statistically higher than Standard control oligo delivered B-1F cells (Fig. 4), or higher than B-1F cells incubated with only delivery solution. The delivery of M-anti oligo into B-1F cells caused the decrease of contents of LTs and 5-HETE in the cells and medium (Fig. 5). The activity of 5-LOX was lower in M-anti oligo delivered B-1F cells than in Standard control oligo

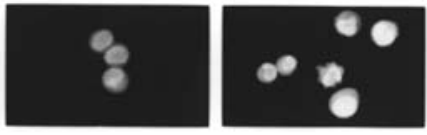

Figure 6. Effect of LTD4 on the growth of B-1 F cells and LTD4 induced apoptosis in B-1F cells. B-1F cells were cultured with various concentrations of LTD4 in the presence of $10^{-8} \mathrm{M} \mathrm{E} 2$. The number of viable cells per dish was counted on day 6 . The values are given as a percentage of the number per dish without LTD4 (A). Columns, means of four determinations; bars, $\mathrm{SE}$. The other 2 separate trials also gave similar results. DNA fragmentation analysis was carried out (B). B-1F cells were cultured in the presence of E2 with (LTD4) or without LTD4 (E2). Lane N, E2 and LTD4 were not added. For morphological examination (C), B-1F cells were stained with Hoechst 33342 and examined by fluorescence microscopy. (a) None; (b) E2; (c) LTD4.

delivered B-1F cells. The activity of PLA2, estimated by arachidonic acid release, was not significantly affected (Fig. 5).

Inhibition of $B-1 F$ cell growth and induction of apoptosis by LTD4. In order to confirm the role of LT in estrogen-responsive growth of B-1F cells, various concentrations of LTD4 were added in the culture medium and cell growth was examined after 6 days. As shown in Fig. 6A, the increasing concentrations of LTD4 resulted in a significant inhibition of cell yields of E2-treated B-1F cells. These results were similar to our previous report (15). The cells were stained with Hoechst 33342 and examined by fluorescence microscopy. Morphological changes, such as nuclear condensation and fragmentation, were observed in B-1F cells treated with LTD4 (Fig. 6B). DNA fragmentation analysis was also carried out. In apoptotic cells, double-strand cleavage occurs in the linker regions between nucleosides and produces DNA fragments. These fragments were demonstrated by agarose gel electrophoresis as a DNA ladder pattern, a typical feature of apoptosis, following 4 days of treatment with LTD4 in E2-stimulated $\mathrm{B}-1 \mathrm{~F}$ cells as well as in control cells cultured in the basal medium (Fig. 6C). These showed LD4 induced apoptosis in $\mathrm{B}-1 \mathrm{~F}$ cells even if in the presence of estrogen.

\section{Discussion}

E2 stimulated the growth of B-1F cells in a dose-dependent manner in vitro. B-1F cells inoculated s.c. into intact adult male mice showed similar estrogen-responsive behavior in vivo. The incidence of tumor growth was $50-60 \%$. Histological analysis of the tumor demonstrated characteristics of malignant tumor such as many mitotic figures, and atypical cell and nuclear features. Our present results, together with our previous results, 
implicate the important role of 5-LOX in estrogen-responsive growth enhancement of B-1F cells. The exogenous addition of LTs in the cultured medium led to a reduction of the proliferation and induced apoptosis of B-1F cells. It was considered that the inhibition of LT production by estrogen resulted in an enhancement of B-1F cell growth. One possible explanation for the inhibition of LT production by estrogen was the reduction of 5-LOX itself as shown in this experiment. As an additional possibility, catechol estrogens, the metabolites of estrogens, might modulate LT synthesis in B-1F cells, although the metabolism of E2 in B-1F cells was not examined in this study. In A23187-stimulated human whole blood, catechol estrogens are reported to be potent 5-LOX inhibitors (23). The reduction of the catalytically active ferric enzyme to the catalytically inactive ferrous form is shown as a possible mechanism for the regulation of lipoxygenase activity by catechol estrogens $(23,24)$. Moreover, interestingly, a bioactive form of E2, such as estradiolquinone, is suggested to interact with the LTD4 receptor to induce granulocytic differentiation in myeloblasts (25).

Tumor growth is enhanced by the suppression of negative growth control and the stimulation of positive growth control. In B-1F cells, estrogen appears to demonstrate its growth promotion ability in part by the suppression of negative growth control. Probably, this mechanism is not the only one for estrogen's effects on B-1F cell growth, and there might be other pathways in which estrogen stimulates positive growth control.

Many reports on the role of LOX in tumor growth have shown the growth stimulatory potency of LOX products (26-29). Moreover, possible correlations are shown of cysteinyl leukotriene (1) receptor [CysLT(1)R] to COX-2, 5-LOX and $\mathrm{Bcl}-\mathrm{x}(\mathrm{L})$ (30). An increased localization of CysLT(1)R in the nucleus of colorectal adenocarcinoma cells has been reported (31). The existence of constitutive CysLT(1)R signalling that mediates both survival and proliferation is revealed in intestinal cells, proposing that tumor-derived intestinal cells are resistant to CysLT(1)R antagonist-induced apoptosis, a phenomena that could be explained by nuclear CysLT(1)R (32). In other reports, LOX metabolites of arachidonic acid inhibited the growth (33-35). In addition to LOX metabolism of arachidonic acids, it has been reported that LOX metabolism of linoleic acids plays important roles in carcinogenesis (10). Reasons for these controversial results, including our results, are unknown. Since the estrogen-responsive element in the upstream of the mouse 5-LOX gene has not been recognized, the mechanism of the decrease of 5-LOX expression by E2 in B-1F cells is not clear. Further study might help to clarify these issues.

\section{Acknowledgements}

The technical assistance of Mrs. Miyazono K is gratefully acknowledged.

\section{References}

1. Nishizawa Y, Sato B, Miyashita Y, Tsukada S, Hirose T, Kishimoto $\mathrm{S}$ and Matsumoto K: Autocrine regulation of cell proliferation by estradiol and hydroxytamoxifen of transformed mouse Leydig cells in serum-free culture. Endocrinology 122: 227-235, 1988 .
2. Ara G and Teicher B: Cyclooxygenase and lipoxygenase inhibitors in cancer therapy. Prostaglandins Leukot Essent Fatty Acids 54: 3-16, 1996.

3. Zeldin D: Epoxygenase pathways of arachidonic acid metabolism. J Biol Chem 276: 36059-36062, 2001.

4. FitzGerald GA: Prostaglandins, aspirin, and related compounds. In: Cecil Textbook of Medicine. Ausiello D (ed). Saunders, Philadelphia, pp155-161, 2004.

5. Phillips R, Wallace MH, Lynch P, Hawk E, Gordon G, Saunders B, Wakabayashi N, Shen Y, Zimmerman S, Godio L, Rodrigues-Bigas M, Su L, Sherman J, Kellof G, Levin B and Steinbach G: A randomised, double blind, placebo controlled study of celecoxib, a selective cyclooxygenase 2 inhibitor, on duodenal polyposis in familial adenomatous polyposis. Gut 50: 857-860, 2002.

6. Steinbach G, Lynch P, Phillips R, Wallace MH, Hawk E, Gordon G, Wakabayashi N, Saunders B, Shen Y, Fujimura T, Su L and Levin B: The effect of celecoxib, a cyclooxygenase-2 inhibitor, in familial adenomatous polyposis. N Engl J Med 342: 1946-1952, 2000

7. Levy G: Prostaglandin H synthases, nonsteroidal anti-inflammatory drugs, and colon cancer. FASEB J 11: 234-247, 1997.

8. Janne P and Mayer R: Chemoprevention of colorectal cancer. N Engl J Med 342: 1960-1968, 2000

9. Piazza G, Rahm A, Krutzsch M, Sperl G, Paranka N, Gross P, Brendel K, Burt R, Alberts D and Pamukcu R: Antineoplastic drugs sulindac sulfide and sulfone inhibit cell growth by inducing apoptosis. Cancer Res 55: 3110-3116, 1995.

10. Shureiqi I and Lippman SM: Lipoxygenase modulation to reverse carcinogenesis. Cancer Res 61: 6307-6312, 2001

11. He T, Chan T, Vogelstein B and Kinzler K: PPARdelta is an APC-regulated target of nonsteroidal anti-inflammatory drugs. Cell 99: 335-345, 1999.

12. Yao R, Rioux N, Castonguay A and You M: Inhibition of COX-2 and induction of apoptosis: two determinants of nonsteroidal anti-inflammatory drugs' chemopreventive efficacies in mouse lung tumorigenesis. Exp Lung Res 26: 731-742, 2000.

13. Nishizawa Y, Nishii K, Nishizawa Y, Koga M, Kishimoto S, Matsumoto K and Sato B: Effects of estrogen on cell proliferation and leukotriene formation in transformed mouse Leydig cells cultured under serum-free conditions. Cancer Res 50: 3866-3871, 1990.

14. Nishizawa Y, Nishii K, Kishimoto S, Matsumoto K and Sato B: Regulatory role of arachidonic acid-derived metabolites for proliferation of transformed murine Leydig cell in serum-free culture condition. Anticancer Res 10: 317-322, 1990.

15. Nishii K, Nishizawa Y, Nishizawa Y, Matsumoto K and Sato B: Inhibition of murine transformed Leydig cell proliferation by leukotrienes in serum-free culture. Cancer Res 51: 5573-5578, 1991.

16. Nishizawa Y, Yamamoto T, Taniguchi $\mathrm{H}$ and Sato B: Effects of estrogen and leukotrienes on anchorage-independent growth of transformed mouse Leydig cells under serum-free condition. Steroid Biochem (Life Sci Adv) 11: 23-28, 1992.

17. Sato B, Hirose T, Kasayama S, Takabayashi H, Koga M and Nishizawa Y: Transformed murine Leydig cells in serum-free culture: useful model for analysis of steroid hormone-induced cell growth and cell morphology (Review). Int J Oncol 1: 415-423, 1992.

18. Nishizawa Y, Nishizawa Y, Yamamoto T, Terada N, Amakata Y, Matsumoto $\mathrm{K}$ and Sato B: Progression of mouse transformed Leydig cells from estrogen-sensitive to estrogen-insensitive growth phenotype concomitant with loss of leukotriene D4 receptor. Int J Oncol 5: 1077-1084, 1994.

19. Nishizawa Y, Yamamoto T, Terada N, Fushiki S, Amakata Y and Nishizawa Y: Effects of antiallergic drugs on the proliferation of estrogen-sensitive mouse Leydig cell line. Anticancer Res 16: 1241-1246, 1996.

20. Henning R, Ding X-Z, Tong W-G, Schneider MB, Standop J, Friess H, Buchier MW, Pour PM and Adrian TE: 5-Lipoxygenase and leukotriene B4 receptor are expressed in human pancreatic cancers but not in pancreatic ducts in normal tissue. Am J Pathol 161: 421-428, 2002

21. Tong W-G, Ding X-Z, Henning R, Witt RC, Standop J, Pour PM and Adrian TE: Leukotriene B4 receptor antagonist LY293111 inhibits proliferation and incuces apoptosis in human pancreatic cancer cells. Clin Cancer Res 8: 3232-3242, 2002.

22. Ashida Y, Saijo T, Kuriki H, Makino H, Terao S and Maki Y: Pharmacological profile of AA-861, a Lipoxygenase inhibitor. Prostaglandins 26: 955-972, 1983. 
23. Alanko J, Sievi E, Lahteenmaki T, Mucha I, Vapaatalo H and Parantainen J: Catechol estrogens as inhibitors of leukotriene synthesis. Biochem Pharmacol 55: 101-104, 1998.

24. Kemal C, Louis-Flamberg P, Krupinski-Olsen R and Sh A: Reductive inactivation of soybean lipoxygenase by catechols: a possible mechanism for regulation of lipoxygenase activity. Biochemistry 26: 7064-7072, 1987.

25. Dietsch V, Kalf GF and Hazel BA: Induction of granulocytic differentiation in myeloblasts by 17-beta-estradiol involves the leukotriene D4 receptor. Receptors Signal Transduct 6: 63-75, 1996.

26. Avis IM, Jett M, Boyle T, Vos MD, Moody T, Treston AM, Martinez M and Mulshine JL: Growth control of lung cancer by interruption of 5-lipoxygenase-mediated growth factor signaling. J Clin Invest 97: 806-813, 1996.

27. Buckman D, Hubbard N and Erickson K: Eicosanoids and linoleate-enhanced growth of mouse mammary tumor cells. Prostaglandins Leukot Essent Fatty Acids 44: 177-184, 1991.

28. Gati I, Bergstrom M, Csoka K, Muhr C and Carlsson J: Effects of the 5-lipoxygenase inhibitors AA-863 and U-60,257 on human glioma cell lines. Prostaglandins Leukot Essent Fatty Acids 40: 117-124, 1990.

29. Rioux $\mathrm{N}$ and Castonguay A: Inhibitors of lipoxygenase: a new class of cancer chemopreventive agents. Carcinogenesis 19: 1393-1400, 1998.
30. Ohd JF, Nielsen CK, Campbell J, Landberg G, Lofberg H and Sjolander A: Expression of the leukotriene D4 receptor CysLT1, COX-2 and other cell survival factors in colonrectal adenocarcinomas. Gastroentorology 124: 57-70, 2003.

31. Nielsen C, Campbell J, Ohd J, Morgelin M, Riesbeck K, Landberg $G$ and Sjolander A: A novel localization of the Gprotein-coupled CysLT1 receptor in the nucleus of colorectal adenocarcinoma cells. Cancer Res 65: 732-742, 2005.

32. Paruchuri S, Mezhybovska M, Juhas $M$ and Sjolander A: Endogenous production of leukotriene D(4) mediates autocrine survival and proliferation via CysLT(1) receptor signalling in intestinal epithelial cells. Oncogene: May 2022 [Epub ahead of print], 2006.

33. Gualde N, Atluru D and Goodwin J: Effect of lipoxygenase metabolites of arachidonic acid on proliferation of human $\mathrm{T}$ cells and T cell subsets. J Immunol 134: 1125-1129, 1985.

34. Werner E, Walenga R, Dubowy R, Boone S and Stuart M: Inhibition of human malignant neuroblastoma cell DNA synthesis by lipoxygenase metabolites of arachidonic acid. Cancer Res 45: 561-563, 1985.

35. van Hilten J, Ben Efraim S, Zijlstra F and Bonta I: Leukotriene C4 is an essential 5-lipoxygenase intermediate in A23187induced macrophage cytostatic activity against P815 tumor cells. Prostaglandins Leukot Essent Fatty Acids 39: 283-290, 1990 